Article

\title{
Focused Coordination Models towards Sustainability in Higher Education. Case of Quevedo State Technical University (Ecuador)
}

\author{
Cristina Checa ${ }^{1}\left(\mathbb{D}\right.$, Carmen De-Pablos-Heredero ${ }^{2, *} \mathbb{0}$, Yenny Guiselli Torres ${ }^{3}$, \\ José Luis Montes-Botella ${ }^{4}$, Cecilio Barba ${ }^{1}$ and Antón García ${ }^{1}$ () \\ 1 Animal Science Department, University of Cordoba, Rabanales University Campus, 14071 Cordoba, Spain; \\ pa2chmoc@uco.es (C.C.); cjbarba@uco.es (C.B.); pa1gamaa@uco.es (A.G.) \\ 2 Department of Business Economics (Administration, Management and Organization), Applied Economics II \\ and Fundamentals of Economic Analysis, ESIC Business \& Marketing School, Rey Juan Carlos University, \\ Paseo de los Artilleros s/n, 28032 Madrid, Spain \\ 3 Animal Science Department, Quevedo State Technical University, Carlos J. Arosemena Av., 120301 Quevedo, \\ Ecuador; ytorres@uteq.edu.ec \\ 4 Department of Applied Economy I, Rey Juan Carlos University, Paseo de los Artilleros s/n, \\ 28032 Madrid, Spain; joseluis.montes@urjc.es \\ * Correspondence: carmen.depablos@urjc.es
}

Received: 1 June 2020; Accepted: 15 July 2020; Published: 17 July 2020

check for updates

\begin{abstract}
This research studied the relationship between coordination models (CM) focused on sustainability and satisfaction, as a competitive advantage, which increases sustainability at the Quevedo State Technical University (UTEQ) in Ecuador. A survey in situ on a random sample of 3200 students was done in 2019. By using multivariate methods, an organizational typology was built. Next, CM were related to the level of student satisfaction by general linear model (GLM). Twenty-three organizational variables were grouped into six components that explained $66.23 \%$ of the variance. A typology with three groups was built: Cluster 1 with a moderate CM level $(44.57 \%$ of the sample), Cluster 2 with a low level of CM (38.18\%), and Cluster 3 with a high level of CM $(15.25 \%)$. By GLM, a positive relation between typology and students' levels of satisfaction was found. Therefore, an increase of CM turned into a major satisfaction level at UTEQ. We suggest, as a priority, to improve communication amongst students and administrative staff. Communication should be frequent, accurate, on time, and oriented to solve problems. It would also be positive to increase the $\mathrm{CM}$ amongst students and representatives in solving communication problems, sharing knowledge, goals, and mutual respect.
\end{abstract}

Keywords: relational models; organizational typology; organizational practices; sustainability

\section{Introduction}

The higher education system is facing broadening global sustainability crises (ecological, learning system, organization, training, skills, etc.) and both, staff of universities and civil society are calling for a transition towards more sustainable education model, with higher quality, productivity, efficiency, resilience, stability, and viability in the long run. In developing countries, improving education is a strategic objective that contributes to increasing the value of people's human capital and favors sustainable territorial development [1,2]. The improvement has been focused on three key aspects: The increase in investments in infrastructure, technological equipment, and academic training of human resources (magister and doctoral thesis) [2,3]. Now, universities are making efforts to develop appropriate research and teaching skills in human capital to increase knowledge management. 
In order to achieve this, they have adopted quality management principles as the key to success [4]. Organizations generate synergies and trade-offs within their production processes and amongst stakeholders. Interactions affect the economic, social, and environmental dimensions of sustainability. A new model capable of providing operational solutions for managing this transition, with the need for an in-depth transformation of the modes of organization in the higher education system is required [5].

The risk of new public health scenarios and economic crises emerging is still rising. In the time of globalization and dynamic changes, education is becoming the decisive force of successful enterprise [6], i.e., the outbreak of COVID-19 has posed a global challenge to the sustainability of the university system. The Coronavirus Disease 2019 has caused different effects on higher education in developing countries: Investments slowdown, questioning the economic viability of universities, and an increase of preventive public health measures with structural changes in the teaching and organizational model $[7,8]$. On the one hand, the acquisition of new sustainable digital skills in higher education favors the generation of added values for students [9-11]. On the other hand, sustainability dimensions need to be integrated into the structure of the organizations [12].

In this process of accelerated change, Latin countries show as a strength the low or free cost of university studies and as a great weakness the administrative, organizational processes and the interrelationships between the different agents that make up the university $[13,14]$. The most recent advances in the field of sustainable development have contributed to collect evidence about the fact that modern organizations need to motivate employees to prosper within this fast-moving scenario. The challenges brought about by global competition, are pushing organizations to rethink their strategies, processes, and practices, and to consider human capital as the main intangible asset that could make new dynamic capabilities and sustainable competitive advantages [15]. Improving organizational processes emerges as a sustainability factor, putting the emphasis on the increase of the value of the human capital of the university. Additionally, the intangible assets represent a factor contributing to the increase of the quality of internal processes, which subsequently generates value $[6,11]$.

In the case of higher education, as in any other organization, the main objective is to obtain better results in a sustainable way. Therefore, it is important to identify organizational practices aimed at achieving this objective so that they can become reference starting points $[13,14]$. Student satisfaction results from the internal functioning of the university [16], and relational and communication ties become key elements to be considered [11]. In this sense, Gallego et al. [10], Margalina et al. [11], and De-Esteban [17] analyzed these ties amongst different stakeholders, faculty, students, and administrative staff in higher education. A relational coordination model (RC) with two dimensions was built [18]: The first one includes variables related to communication amongst stakeholders, such as accurate, frequent and problem-solving communication [19]. The second dimension was linked to shared knowledge, mutual respect, and shared objectives. These dimensions oriented to the integration of tasks influenced the quality, safety, and efficient performance of the organization.

RC model was applied to different industries: In health, with the nurse job satisfaction and the improvement of the organ transplant system in Spain $[19,20]$, and in the textile industry and its effect on corporate social responsibility [21]. Results showed that the improvement in communication amongst the stakeholders was related to an increase in final organizational results [20]. RC models in online education at Alcalá de Henares and Rey Juan Carlos Universities (Spain) were built previously [10,11] and highlighted the influence of communication and its relationship with quality. They were also built for face-to-face learning, i.e., in a comparative analysis amongst Arcada University (Finland), Cordoba University (Spain), and Agricultural Polytechnic School of Manabí (Ecuador) [22]. This research built a preliminary relational coordination model in higher education at the Quevedo State Technical University (UTEQ), face-to-face students in different areas of knowledge were considered, and RC was related to quality [3]. In previous research, structural changes according to student's accumulated experience were identified and a measure of student's satisfaction was proposed [14,23]. 
Since 2011, Ecuadorian universities have been implementing structural reforms in order to achieve sustainable development goals, but nowadays, the development of best organizational practices is becoming the key factor. Relating higher education organization with relational coordination is an advance in research, with the assumption that an increase in coordination favors the improvement of results and sustainability. The management of good practices inside the organizations allows achieving competitive advantages and useful strategies to secure organizational survival in a turbulent market [15]. Therefore, it would be interesting to go deep in the knowledge of the relational coordination model focused on the sustainability of the university and its relationship with students' satisfaction level [13]. In this research, we have analyzed the relation and communication ties among the different stakeholders of the organization. Improved coordination in the organization was linked to an increase in student satisfaction and focused on increasing the sustainability of the system as a competitive advantage [11,12]. We have considered sustainability, as a state of system functioning and the coordination as the way stakeholders interconnect, all this with the purpose to achieve the well-coordinated functioning and sustainable development of the system. Therefore, the aspect of sustainability is important here, as well. What are the flaws in the organizational model of small universities in Latin-American developing countries that compromise their sustainability in the medium term? This general objective motivated the conduct of this study, taking the UTEQ as a case of the small-scale organization, and located in an agrarian and disadvantaged area in a developing country, although the problem was similar to that of other small-sized universities disseminated throughout Latin America and the Mediterranean basin.

This research allowed us to answer the following research-specific questions: Are there different typologies of students according to the existing communication and relational ties for sustainability at the university? Does an organizational improvement strategy favor the sustainability of the system by increasing student satisfaction? Are these organizational models linked to high levels of student satisfaction? Within each typology, which best organizational practices of relational coordination should be improved if student satisfaction is to be increased? Therefore, the objective of this research was to assess the relationship among the organizational models and level of satisfaction on higher education in the case of an Ecuadorian university. Firstly, an organizational typology was built through multivariate methods in UTEQ. In the second stage, the coordination models (CM) focused on sustainability were linked to the level of student's perceived satisfaction (GLM).

Research questions have been identified in Section 1. Section 2 provides a brief introduction of higher education as a service quality that pursues student satisfaction, Section 3 is dedicated to the materials and methods, Section 4 presents results, Section 5 offers the discussion of the research, and Section 6 offers the conclusion.

\section{Higher Education as a Service Quality}

The improvement in quality is a strategic objective in higher education, that combines tangible and intangible factors to reach objectives and satisfy student's expectations [24,25]. Satisfaction relates to the expectations of the student with the results obtained. This way, the student is considered as a client who receives the services of the university as an organizational entity $[1,26]$. The level of satisfaction with educational experience is a very important component of the evaluation of an institution and a global sustainability factor [27]. Satisfaction is an outcome of service quality and student satisfaction has thus become one of the major goals of universities. A satisfied student population is a source of competitive advantage with outcomes such as positive word of mouth communication, student retention, and loyalty [28].

Within this quality assessment process, student satisfaction was measured in most part of universities. As part of their managerial practices, regular universities collected information through surveys to monitor levels of student satisfaction. Results relied primarily on students' perceptions of the quality of physical facilities and the instruction offered $[29,30]$.

Different studies related satisfaction with positive student perceptions of the quality of the services provided by the university $[1,31]$. In this sense, a study in Pakistan adapted an instrument used in 
service industries to assess student satisfaction in business schools [4]. There is extensive research identifying the factors on satisfaction in the universities. Student satisfaction was a multi-dimensional process influenced by many factors [32]. The review realized showed the background for understanding university student satisfaction. Table 1 shows the organizational factors that influence satisfaction and the methodology used.

Table 1. Satisfaction factors in higher education.

\begin{tabular}{|c|c|c|}
\hline Methodology & Factors & Authors \\
\hline Multidimensional scaling (MDS) & $\begin{array}{l}\text { Organizational services * } \\
\text { Services of didactic activities * } \\
\text { Additional services * } \\
\text { Inefficient services * } \\
\text { Services linked to the staff * }\end{array}$ & [33] \\
\hline Friedman test & $\begin{array}{l}\text { Teaching staff* } \\
\text { Administrative support* } \\
\text { Program issues * } \\
\text { Physical environment * } \\
\text { Location of the institution * } \\
\text { Social life * } \\
\text { Support facilities * }\end{array}$ & [27] \\
\hline General linear model (GLM) & $\begin{array}{l}\text { Lectures* } \\
\text { Student representatives * } \\
\text { Administration staff* } \\
\text { Materials * } \\
\text { Communication channels * } \\
\text { Training contents * }\end{array}$ & [22] \\
\hline Descriptive statistical & $\begin{array}{l}\text { Instruction * } \\
\text { Course offering * } \\
\text { Grading * } \\
\text { Testing * } \\
\text { Guidance Rules * } \\
\text { Library School assistance * }\end{array}$ & [34] \\
\hline Structural equation modeling (SEM) & $\begin{array}{l}\text { Tangible assets (infrastructure, etc.) * } \\
\text { Cooperation and support * } \\
\text { Responsiveness * } \\
\text { Reputation * } \\
\text { Reliability * } \\
\text { Student satisfaction * }\end{array}$ & [4] \\
\hline SEM & $\begin{array}{l}\text { Reliability* } \\
\text { Assurance * } \\
\text { Tangible assets * } \\
\text { Empathy * } \\
\text { Responsiveness * }\end{array}$ & [1] \\
\hline SEM & $\begin{array}{l}\text { Accurate communication } \\
\text { Frequent communication } \\
\text { Solving problem communication * } \\
\text { Shared knowledge } \\
\text { Mutual respect* } \\
\text { Shared goals }\end{array}$ & [11] \\
\hline Principal component analysis (PCA) & $\begin{array}{l}\text { Curriculum * } \\
\text { Infrastructure } \\
\text { Preparation * }\end{array}$ & [29] \\
\hline
\end{tabular}


Table 1. Cont.

\begin{tabular}{|c|c|c|}
\hline Methodology & Factors & Authors \\
\hline PCA & $\begin{array}{l}\text { General satisfaction* } \\
\text { Involvement* } \\
\text { Satisfaction with the results * } \\
\text { University reputation * }\end{array}$ & [30] \\
\hline PCA & $\begin{array}{l}\text { Professor * } \\
\text { Course planning } \\
\text { Infrastructure * }\end{array}$ & [26] \\
\hline PCA and linear regression & $\begin{array}{l}\text { Access * } \\
\text { Academic * } \\
\text { Support services * } \\
\text { Non-Academic * } \\
\text { Infrastructure * } \\
\text { Program issues * }\end{array}$ & [35] \\
\hline
\end{tabular}

${ }^{*}$ Factors with differ significantly, $p$-value $<0.05$.

In University of Bari (Italy), 19 variables were retained in six groups: Groups one and two were composed by organizational services; third group, by services strictly related to didactic activities; fourth group, by additional services; fifth group contained inefficient or poorly perceived services, such as administrative services, tutoring, placement; and the sixth group included the services linked to the staff [33]. These variables, such as facilities, student services and support, teaching services and student life, localization of the institution and demographic factors, were common in some research $[27,36]$. Socioeconomic factors influenced the level of satisfaction in multiple ways. An external study of the protests concluded that the dissatisfaction of current students in Chile was prompted more by the anticipation of low economic rewards once graduated than by judgments that their present training was of low quality $[29,37]$.

In Spain, De-Pablos-Heredero et al. [22] built a satisfaction index from: Lectures, student representatives, administration staff, materials, communication channels, and training contents. In Slovenia, by using linear regression analysis, teaching staff, administrative support, program issues, physical environment, location of the institution, social life, and support facilities were highlighted [27]. Action measures were focused on teaching and non-teaching factors, such as the physical environment. In Myanmar, two quality levels (high and low) were determined and significant satisfaction factors were instruction, course offering, grading, testing, rules, and school assistance [34].

Structural equation modeling (SEM) was applied to SERVQUAL variables [1,4]. They stressed the influence of personal factors, such as the student's mood or emotional state and family members' opinions. Ijaz et al. [4] measured satisfaction through loyalty, retention, job assurance, increased learning, and reputation. Margalina et al. [11] showed that high levels of relational coordination between students and teachers explained higher degrees of satisfaction. Problem-solving communication and mutual respect were among the main elements of satisfaction.

Principal components analysis (PCA) was another methodology often used to assess satisfaction $[26,29,30,38]$. The variables of satisfaction of postgraduate students about curriculum, infrastructure and the graduate felt prepared for work in their profession were studied. Self-efficacy and programs with better employment practices were determined as fundamental factors of satisfaction [29]. Palominos-Belmar et al. [30] identified seven satisfaction factors: General user satisfaction, perceived quality of teaching service, perceived quality of administrative service, perceived quality of equipment and infrastructure service, user involvement or co-production, service results and reputation of the institution, where the first four showed a higher explanatory level. Salinas et al. [26] used variables related to teachers, subject planning, and infrastructure, and determined that the main elements of satisfaction were the teacher's attitude, state of classroom maintenance, and information adequacy of the services. Finally, Xuan-Lan and Minh-Tien [35] studied the influence of education 
service quality level on student satisfaction and determined that the explanatory elements of satisfaction were access, academic, support services, non-academic, infrastructure, and program issues.

In Spain, the importance of quality in the university was achieved through satisfaction, trust, image, and shared values [39]. Weng et al. [40] developed and tested a model for improving higher education in China and concluded that the factors that influence satisfaction were lecture performance and the efficient use of resources. Another study in the Slovak Republic showed that active student participation in the educational process, updated content, and education based on job expectations were the satisfaction factors [6]. Apart from this, Marqués-Sánchez et al. [41] verified that the determinants of levels of satisfaction were internal academic performance, resilience, and commitment in cooperative work with classmates. Orozco-Messana [9], Ja-Sawm and Yan [34], and Tsinidou et al. [42] showed the use of Information and Communication Technologies (ICTs) as tools to assess user satisfaction and the quality of learning results. The determining elements of quality were cooperation and capacity development through the use of ICTs. This study was carried out in Azerbaijan, and similar results have been demonstrated as in the case of South Carolina.

\section{Materials and Methods}

\subsection{Data Collection and Survey}

The study area was the Quevedo State Technical University (UTEQ) in the coast of Ecuador, with 9200 students matriculated in 2018 and 191 lecturers. UTEQ was a university with "B" category by the CEAACES (Council of Evaluation, Accreditation and Quality Assurance of Upper Education), in a classification from " $\mathrm{A}$ " up to " $\mathrm{C}$ ", in a decreasing scale [2].

A random sample of 3200 students was considered during the 2018-2019 academic course. It was applied to students with a stay in the university of more than two years and experience in university life. Therefore, the students of first and second year were not considered. The surveys were randomly collected in different branches of knowledge: Social sciences, health, engineering, and life sciences. The sample was significant at 99\% $(p<0.001)$. The survey was used before in other relational coordination studies $[10,11,13]$. The Kaiser-Meyer-Olkin (KMO) and Bartlett test was used to validate the adequacy of sample size. The survey's reliability was verified by means of Cronbach's alpha, with a value of over 0.92 [43].

Data were collected in situ by the same person during an hour-long regular class. During the class, the objectives of the study were explained, and doubts were solved. Then, each question and the potential responses were read to permit answering. The methodology for reading and answering the question was used in the rest of the cases.

Twenty-nine items in a survey were applied: 23 were focused on aspects concerning the coordination model $(\mathrm{CM})$ and six on the level of satisfaction of students with different organizational aspects. Student satisfaction was used as a quality criterion in this work. Communication dimensions described by Gittell et al. [18,19] and applied by Gallego et al. [10] and Margalina et al. [11]: Communication (frequent, timely, accurate, and problem-solving) and relational dimensions (shared goals, shared knowledge, and mutual respect). CM dimensions and satisfaction were tested by the different stakeholders at the organization: Administrative officers and other support staff, student representatives, teaching (academic) staff or lectures, and classmates. All the identified variables (Table 2) recognized organizational aspects of the UTEQ and were strongly related to a sustainable improvement in higher education, both in relation to students, results, and overall satisfaction (Survey applied in Table S1).

All the items were measured through a Likert scale from 1 (non-frequent) to 5 (very frequent). According to Reips and Funke [44], visual analog scale was used. This scale was considered the most appropriate for this study. In this research, the intervals between the scale points corresponded to empirical observations in a metric sense and facilitated their statistical treatment. 
Table 2. Survey items.

\begin{tabular}{|c|c|}
\hline Code & Variable \\
\hline \multicolumn{2}{|c|}{ ACCURATE COMMUNICATION } \\
\hline 1. $\mathrm{ACCU}_{\mathrm{Admin}}$ & Accurate communication with administrative officers \\
\hline 2. $\mathrm{ACCU}_{\text {Lect }}$ & Accurate communication with lecturers \\
\hline 3. ACCU Class & Accurate communication with classmates \\
\hline \multicolumn{2}{|c|}{ FREQUENT COMMUNICATION } \\
\hline 4. FREQ ${ }_{\text {Admin }}$ & Frequent communication with administrative officers \\
\hline 5. FREQ Lect & Frequent communication with lecturers \\
\hline 6. FREQ Class & Frequent communication with classmates \\
\hline \multicolumn{2}{|c|}{ SOLVING PROBLEM COMMUNICATION } \\
\hline 7. SOLPRO Myself $_{1}$ & Problem-solving communication with myself \\
\hline 8. SOLPRO Lect & Problem-solving communication with lecturers \\
\hline 9. $\mathrm{SOLPRO}_{\text {Repres }}$ & Problem-solving communication with student representatives \\
\hline 10. $\mathrm{SOLPRO}_{\mathrm{Admin}}$ & Problem-solving communication with administrative officers \\
\hline 11. SOLPRO & Problem-solving communication with classmates \\
\hline \multicolumn{2}{|l|}{ SHARED KNOWLEDGE } \\
\hline 12. SKNOW Lect & Shared knowledge with lecturers \\
\hline 13. SKNOW Repres & Shared knowledge with student representatives \\
\hline 14. SKNOW $\mathrm{Admin}$ & Shared knowledge with administrative officers \\
\hline 15. SKNOW Class & Shared knowledge with classmates \\
\hline \multicolumn{2}{|l|}{ MUTUAL RESPECT } \\
\hline 16. RESPE Lect & Mutual respect with lectures \\
\hline 17. RESPE Repres & Mutual respect with student representatives \\
\hline 18. RESPE $_{\mathrm{Admin}}$ & Mutual respect with administrative officers \\
\hline 19. RESPE $E_{\text {Class }}$ & Mutual respect with classmates \\
\hline \multicolumn{2}{|l|}{ SHARED GOALS } \\
\hline 20. SHARGOAL Lect & Shared goals with lecturers \\
\hline 21. SHARGOAL Repres & Shared goals with student representatives \\
\hline 22. SHARGOAL $\mathrm{Admin}$ & Shared goals with administrative officers \\
\hline 23. SHARGOAL ${ }_{\text {Class }}$ & Shared goals with classmates \\
\hline \multicolumn{2}{|c|}{ STUDENT SATISFACTION } \\
\hline 24. SATIS Lect $_{1}$ & Satisfaction with lectures \\
\hline 25. SATIS Represent $_{\text {R }}$ & Satisfaction with student representatives \\
\hline 26. SATIS Admin $_{\text {A }}$ & Satisfaction with administrative officers \\
\hline 27. SATIS Materials & Satisfaction with materials \\
\hline 28. SATIS Communic & Satisfaction with communication channels \\
\hline 29. SATIS Contents & Satisfaction with training contents \\
\hline
\end{tabular}

\subsection{Statistical Analysis}

\subsubsection{Typology of Coordination Model (CM)}

The development of the typology was made from the methodology used by Santos and Horta [16], which consists of three stages: Review and selection of variables, principal components analysis, (PCA) and cluster analysis [45-47].

In the first stage, 23 variables of $\mathrm{CM}$ were selected, those with a coefficient of variation higher than $60 \%$. PCA was used in order to reduce the number of variables of $\mathrm{CM}$ and summarize the most variability. Once the components were selected, the orthogonal varimax rotation was applied to relate more easily the selected variables to the extracted components. The PCA can be made when $\mathrm{KMO}$ value is greater than 0.50 and probability of Barlett test is less than 0.05 [45,48]. In addition, Cronbach's alpha was calculated by applying reliability analysis on designated factors [43], scoring over a punctuation of 0.75 in each component.

Once the number of variables was reduced, a hierarchical cluster analysis was done with the dimensions showing the greatest variance generated by the PCA. Cluster analysis allowed grouping the cases that were similar between them (minor within-group variance) and different to the others 
(greater variance between groups). The groupings were done based on Ward's method, using the Euclidean, squared Euclidean, and Manhattan distances. The three consequent groups were studied by ANOVA using post hoc SNK test. This procedure maximizes the homogeneity within groups and the heterogeneity between them [49]. All data were analyzed using statistical software Statgraphics Centurion XVI.I. [50].

\subsubsection{Relationship between Coordination Model (CM) and Satisfaction}

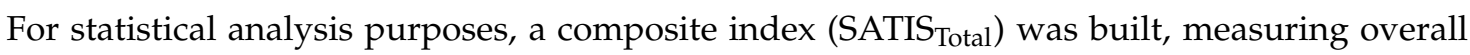
student perception by cumulative values of the six items of satisfaction for each student (from variable 24 to 29). Statistical descriptors of trend, dispersion, and asymmetries of the variable SATIS Total were calculated to check the behavior of this variable at UTEQ [31] (Figure S1).

Once we verified that the specific models are organizationally different, we checked whether they also had different levels of satisfaction. For this, a general lineal model (GLM) was applied. The GLM test allows determining which pairs of means differ significantly and study data whose error does not fit the normal distribution and non-constant variances. The GLM summarize a homogeneous group of regression methods (logistics, Poisson, gamma, etc.), previously considered independently [51].

\section{Results}

PCA retained six factors that explained $66.23 \%$ of variance with an eigenvalue over one (Table 3 ). The first component explained $36.13 \%$ of the variance. It showed the highest values in variables such as accurate communication, frequent communication, problem-solving communication, and shared knowledge. All the variables of this component were related with the profile of administrative officers. This component was called administrative communication. The second component explained $8.58 \%$ of the variance. Problem-solving communication, shared knowledge, mutual respect, and shared goals were the retained variables. The prevailing selected profile in the variables was the student representatives or student leadership. The third component represented $7.25 \%$ of the variance. It showed high scores in variables of relationship dimension, as mutual respect and shared goals, all of them related with lectures profile. In this way, this was lecturer cooperation component. The fourth component explained $5.26 \%$ of variability and, it was associated with variables related to problem-solving communication and some variables of relationship dimension, such as shared knowledge, mutual respect, and shared goals with classmates. Highest scores in this factor were related to the need to proportionate higher levels of problem-solving communication and shared knowledge. This component represented classmate coordination. The fifth one explained $4.59 \%$ of the variance. This component showed high scores in the profiles related to lecturers and classmates in the items of accurate and frequent communication. This component represented classroom communication. Finally, the sixth component, with $4.42 \%$ of the variance, was linked to the individual capacity to solve problems and it is named autonomy.

From the six components, a typology of students was built by cluster analysis. Cluster analysis, which presented significant results, was the solution of three groups with Ward's method, based on the Euclidean distances (Figure 1). The typology obtained correctly classified $71.64 \%$ of the cases $(p<0.001)$. Cluster 1 correctly assigned $71.21 \%$, Cluster $293.79 \%$, and Cluster $388.27 \%$ of the cases. Table 4 shows the main characteristics of each organizational type. Cluster 1 with moderate $\mathrm{CM}$, comprised $46.57 \%$ of the students and intermediate values in the centroids $(p<0.05)$. Cluster 2 with low levels of $\mathrm{CM}$, grouped $38.18 \%$ of the cases and showed negative values in the six components $(p<0.05)$. Cluster 3 with higher levels of $\mathrm{CM}$, grouped $15.25 \%$ of the cases and offered positive values in each component $(p<0.05)$. 
Table 3. Principal components (PC) loading matrix of rotated.

\begin{tabular}{|c|c|c|c|c|c|}
\hline Items & Loading & Eigenvalue & Explained Variance (\%) & $\alpha$ Cronbach & PC \\
\hline 1. $\mathrm{ACCU}_{\mathrm{Admin}}$ & 0.628 & 8.30 & 36.13 & 0.77 & 1 \\
\hline 4. FREQ & 0.732 & & & & \\
\hline 10. SOLPRO $_{\text {Admin }}$ & 0.728 & & & & \\
\hline 14. SKNOW $\mathrm{Sdmin}_{\text {Adm }}$ & 0.651 & & & & \\
\hline 9. SOLPRO $_{\text {Repres }}$ & 0.734 & 1.97 & 8.58 & 0.84 & 2 \\
\hline 13. SKNOW Repres & 0.745 & & & & \\
\hline 17. RESPE $E_{\text {Repres }}$ & 0.756 & & & & \\
\hline 21. SHARGOAL Repres & 0.757 & & & & \\
\hline 16. RESPE $_{\text {Lect }}$ & 0.760 & 1.67 & 7.25 & 0.75 & 3 \\
\hline 20. SHARGOAL Lect & 0.701 & & & & \\
\hline 11. SOLPRO Class & 0.706 & 1.21 & 5.26 & 0.81 & 4 \\
\hline 15. SKNOW & 0.750 & & & & \\
\hline 19. RESPE $E_{\text {Class }}$ & 0.640 & & & & \\
\hline 23. SHARGOAL Class & 0.640 & & & & \\
\hline 2. $\mathrm{ACCU}_{\text {Lect }}$ & 0.678 & 1.56 & 4.59 & 0.76 & 5 \\
\hline 3. ACCU Class & 0.759 & & & & \\
\hline 5. FREQ Lect & 0.618 & & & & \\
\hline 6. FREQ & 0.744 & & & & \\
\hline 7. SOLPROMyself $_{\text {Mys }}$ & 0.623 & 1.02 & 4.42 & - & 6 \\
\hline
\end{tabular}

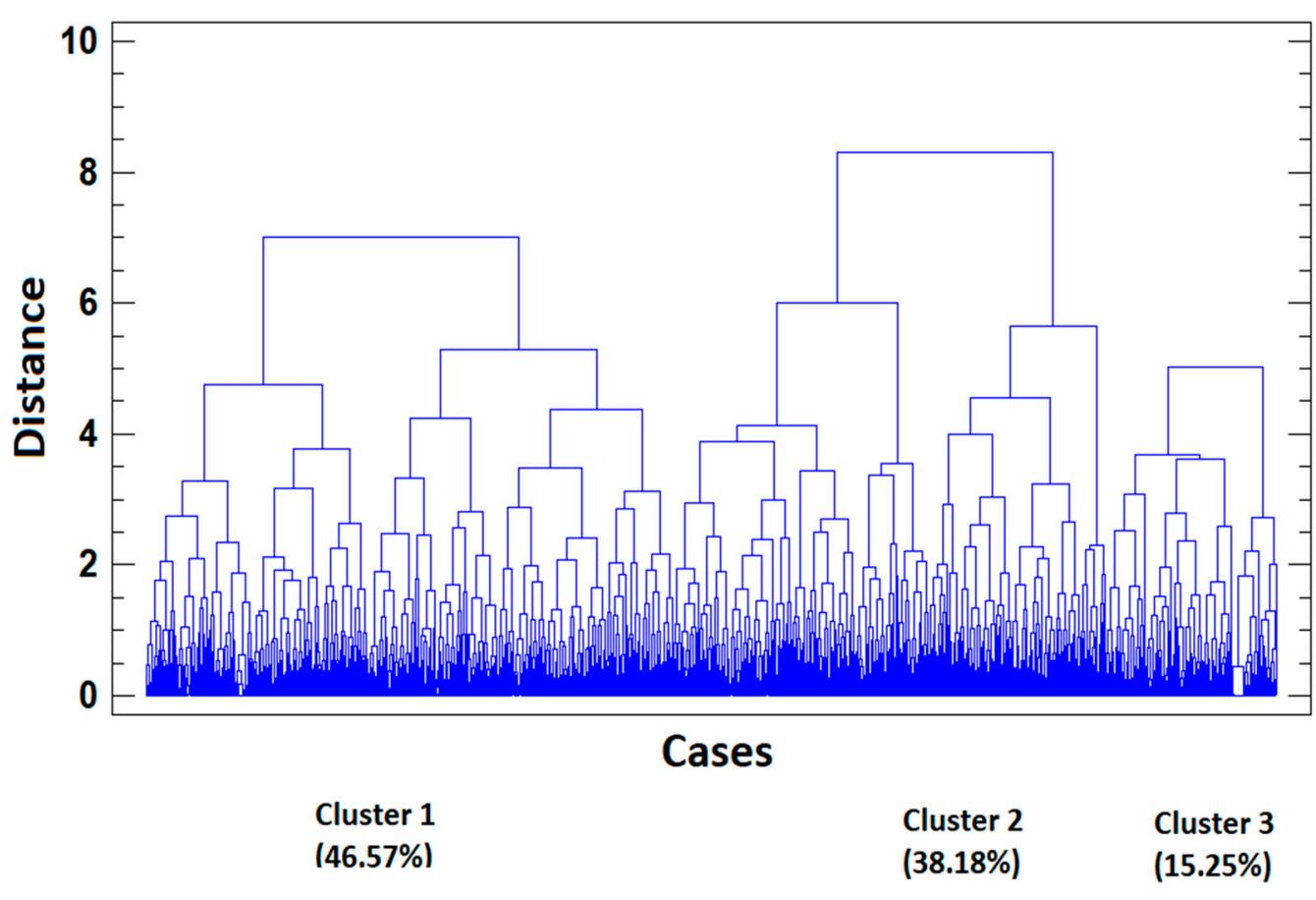

Figure 1. Coordination clusters. 
Table 4. Centroids for each cluster.

\begin{tabular}{lcccc}
\hline \multicolumn{1}{c}{ Components } & PC $^{\mathbf{1}}$ & Cluster $\mathbf{1}$ & Cluster $\mathbf{2}$ & Cluster 3 \\
\hline $\begin{array}{l}\text { Administrative } \\
\text { communication }\end{array}$ & 1 & $1.259^{\mathrm{b}}$ & $-4.023^{\mathrm{a}}$ & $6.231^{\mathrm{c}}$ \\
$\begin{array}{l}\text { Student leadership } \\
\text { Lecture cooperation }\end{array}$ & 2 & $1.282^{\mathrm{b}}$ & $-4.120^{\mathrm{a}}$ & $6.405^{\mathrm{c}}$ \\
$\begin{array}{l}\text { Classmate } \\
\text { coordination }\end{array}$ & 3 & $1.240^{\mathrm{b}}$ & $-3.761^{\mathrm{a}}$ & $5.633^{\mathrm{c}}$ \\
$\begin{array}{l}\text { Classroom } \\
\text { communication }\end{array}$ & 5 & $1.127^{\mathrm{b}}$ & $-3.532^{\mathrm{a}}$ & $5.405^{\mathrm{c}}$ \\
Autonomy & 5 & $0.942^{\mathrm{b}}$ & $-2.834^{\mathrm{a}}$ & $4.221^{\mathrm{c}}$ \\
\hline
\end{tabular}

${ }^{1}$ Principal component. a ${ }^{b},{ }^{c}$ Within row, averages with different superscript differ significantly, $p$-value $<0.001$.

Relationship between Coordination Clusters and Satisfaction Level (SATIS Total $_{\text {) }}$

The satisfaction assessment was low with $23.35 \pm 0.08$ and a coefficient of variation of $18.06 \%$. A kurtosis showed a high concentration of the data and Fisher's asymmetry was negative, finding a greater dispersion of the data in the right part of the distribution, so SATIS Total $_{\text {data were not adjusted }}$ to a normal distribution (Figure S1). In Figure 2, the behavior of the satisfaction level with the first two components is shown. An increase of relational coordination in both components allowed to achieve higher levels in student satisfaction.

Figure 3 showed the relationship between CM and satisfaction (SASTIS ${ }_{\text {Total }}$ ). The General Linear Model showed the relationship between satisfaction and cluster at a trust level of $99 \%$. The adjusted $\mathrm{R}^{2}$ explained a $25.61 \%$ of the satisfaction variance. The same way, the test of Ducan for means comparison showed the existence of significant differences amongst the three groups. The cluster three obtained the highest values of satisfaction in comparison to Cluster 2 with the lowest values $(p<0.001)$. In Cluster 1 , values close to the mean were obtained. The density function of the satisfaction variable was different for each cluster (Figure S1).

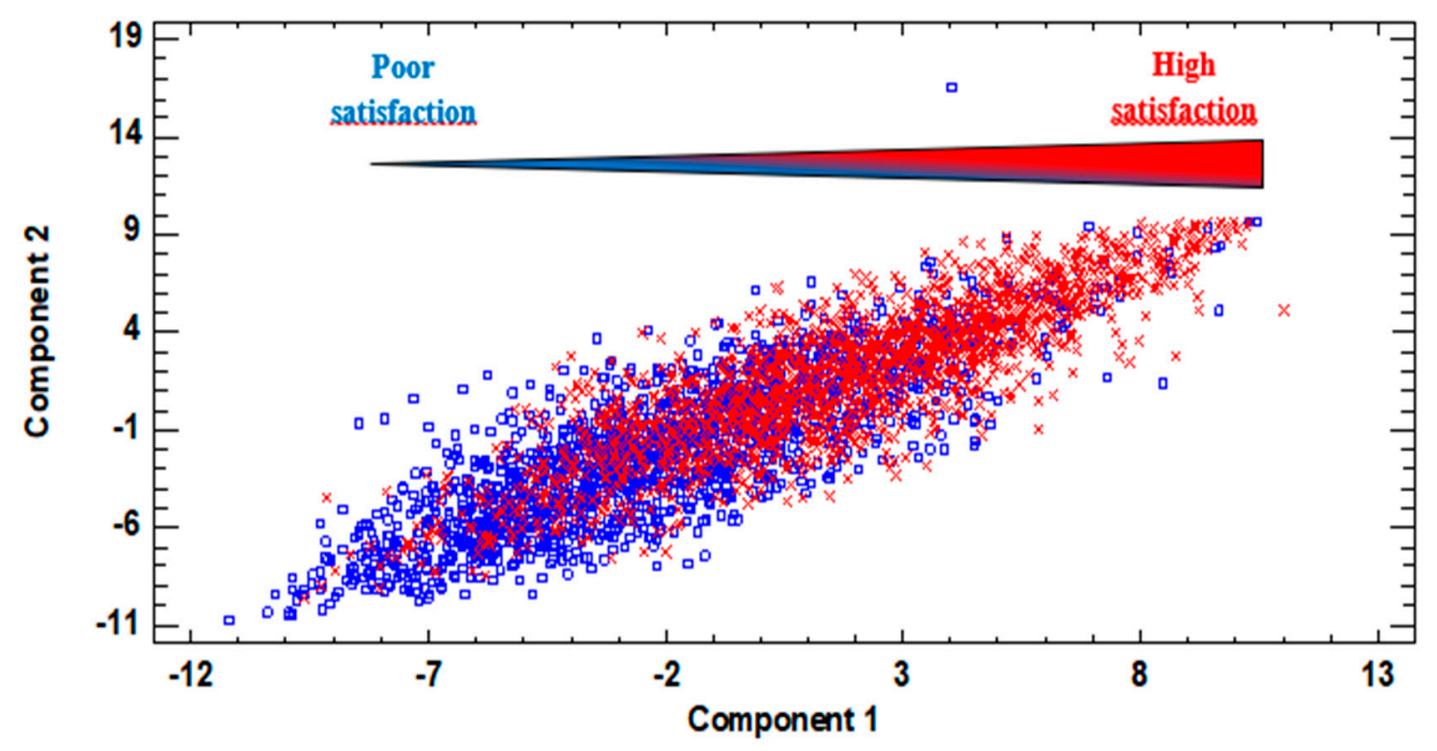

Figure 2. Satisfaction according to the first two components. 


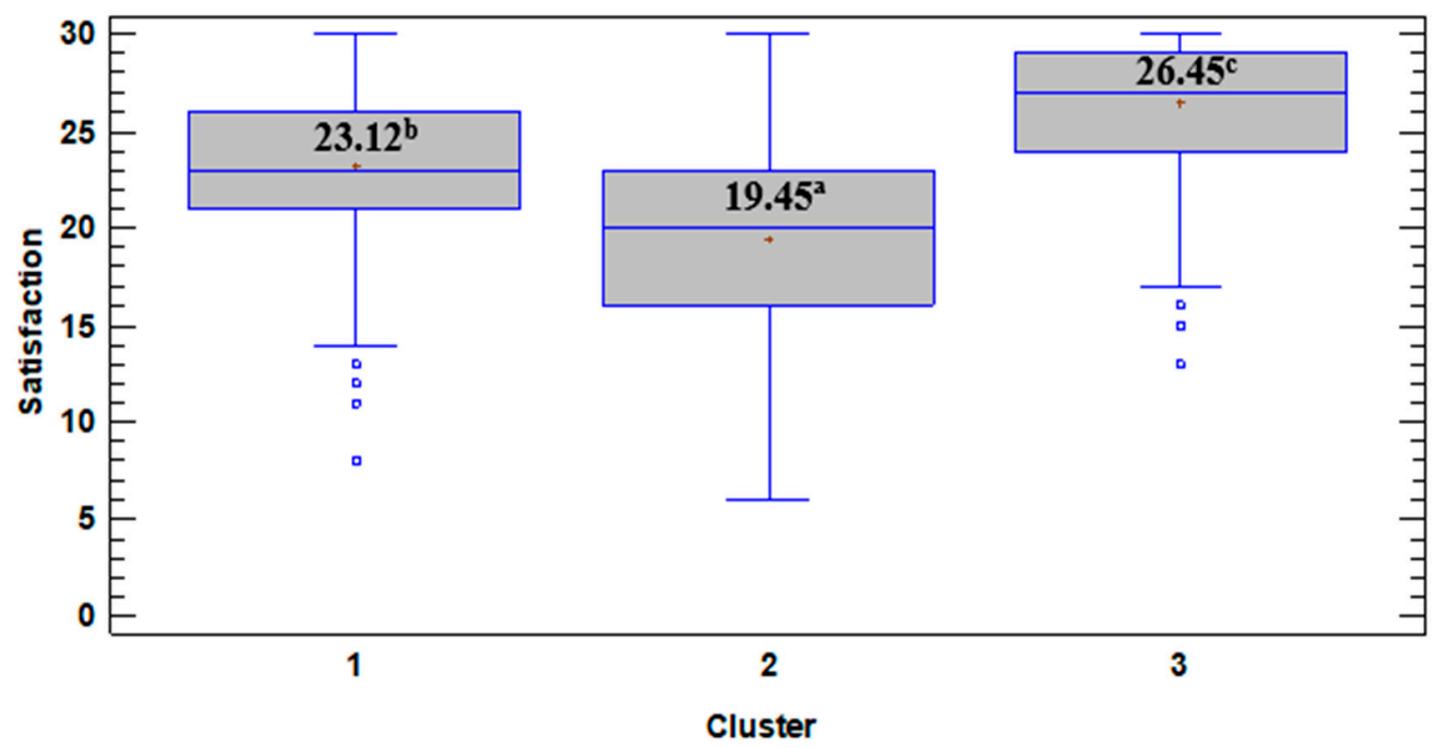

Figure 3. Total satisfaction in each coordination cluster. Mean ${ }^{a, b}, \mathrm{c}$ with different superscript differ significantly, $p$-value $<0.001$.

\section{Discussion}

According to Ainscough et al. [52] and Ballantine et al. [53], the methodology used has allowed identifying variables and grouping them in organizational factors by means of an exploratory analysis. A typology was built with three groups according to organizational variables: High CM (Cluster 3), low CM (Cluster 2), and moderate CM (Cluster 1). Besides, a significant and positive relationship between CM and the level of student's perceived satisfaction was found $(p<0.001)$ (Figure 3).

The research carried out is of great interest because we have identified the key organizational factors in the existing relational coordination models at the UTEQ. The organizational factors agreed with results obtained in previous studies in UTEQ, Arcada University (Finland), Cordoba University (Spain), Agricultural Polytechnic School of Manabí (Ecuador) and Salamanca University (Spain) [13,14,22,31]. The organizational model is similar to previous studies in UTEQ, University of Malaysia and the research of comparison between a South Korean University and a university in the USA, and facilitates the identification of structural problems $[14,23,54,55]$. However, the retained factors are different from findings in online learning reported at Norwich University, Alcalá de Henares, and Rey Juan Carlos Universities [10].

Considering the proposed typology and its relationship with satisfaction is a useful tool to focus the effort on improving those organizational practices that increase the performance $[10,11]$.

The results suggest that the UTEQ should be focused on improving the organizational practices collected that explained the $44.71 \%$ of the variance and were strongly linked to administrative communication (first component) and the student leadership (second component).

The administrative officer is a stakeholder of great interest in higher education by applying the principles of quality customer service [27]. Sohail and Shaikh [36] found that the contact personnel were the most influencing factor in students' evaluation of service quality. According to Tsinidou et al. [42], students saw the administrative officer as an authoritative source of information on matters relating to their studies and placed great importance on receiving good advice. In this sense, Xuan-Lan and Minh-Tien [35] recommend that the university offices need to simplify the administrative processes, increase opening hours, and provide students with the contact information of the staff in charge in order to ensure swift problem-solving process for students. In this case, results show the need for administrative officers to improve the quality of the information, i.e., accurate and frequent communication, response times oriented to solving problems. Besides, administrative officers must be closer, empathize more with the students in the knowledge of the problem. 
The second organizational component of interest was the relational coordination between students with student representatives. Results suggested that an improvement in this dimension of CM (solving problem communication, shared knowledge, mutual respect, and shared goals with student leaders) will promote an increase of satisfaction. The bibliography that deepens the relationship between the student and student leadership is insufficient. According to Ja-Sawm and Yan [34] in Kant Kaw Education Center in Myanmar, students were not satisfied with student representative council, by indicating that it should be improved. Students also mentioned individual benefits for student representatives [56]. In connection with this, Kucharcikova et al. [6] indicated that the sustainability of education at universities would be supported, contributing to the increase of the value of students' human capital. The results obtained agree with Filho et al. [57] that showed challenges seen in implementing sustainability leadership, i.e., a lack of interest by the university administration and among some members of the academic community. On the other hand, Lee et al. [58] suggested a method to lessen information asymmetry and conflict of goals with leaders, such as a performance-based organizational system and an incentive-based budget system.

The research is highly applicable. By properly improving concrete organizational practices at the UTEQ, student satisfaction could improve. An improvement in the communication and relationship of the UTEQ favors an increase in satisfaction, long-term viability, and organizational sustainability of the university $[11,20]$. Hopefully, the improvement of organizational practices in the two first components (with high explained variance) will promote a strong increase of relational coordination, although with a non-linear response according to the law of decreasing returns $[2,17]$. However, this research presents two important limitations. It is exploratory and further research evaluating the incidence in the improvement of organizational practices in the final results (satisfaction and quality), through logistic regression, structural equation model (SEM), identifying the causes of inefficiencies with data envelopment analysis, etc. is welcomed [38]. Apart from this, more information is required about the relationship between students and representatives in such a way that it will help understanding this relationship.

\section{Conclusions}

Twenty-three organizational variables were identified and grouped into six factors that explain $66.23 \%$ of the variance in a significant and reliable way. Surprisingly, the results showed that the communication between students and administrative officers is the most important factor of satisfaction at UTEQ. Findings show that there were different groups of students according to the existing communication and relational ties for sustainability at the UTEQ. According to the typology, three organizational models were obtained and $71.64 \%$ of the cases were correctly classified. Cluster 1 with moderate CM, grouped $46.57 \%$ of the students, Cluster 2 with low levels of CM, grouped $38.18 \%$ of cases, and Cluster 3 with high levels of CM grouped $15.25 \%$ of the cases. We found a strong positive relationship between coordination models focused on sustainability and level of student's perceived satisfaction. Cluster 3 showed a high level and Cluster 2 exhibited a poor level of satisfaction. An organizational improvement strategy increased the student satisfaction, improved competitive advantages and more sustainable higher education system.

The identified key organizational practices would allow the UTEQ to act immediately and specifically. We suggest the improvement in communication (quantity and quality), amongst students and administrative staff (accurate, on time and appropriate to solving problems). Apart from this, it would be important to improve relational coordination amongst students and representatives. Both relational coordination practices will favor sustainability in higher education of the UTEQ in Ecuador. The results obtained could be applied to other universities with face-to-face training disseminated throughout Latin America and the Mediterranean basin with similar socioeconomic contexts. 
Supplementary Materials: The following are available online at http://www.mdpi.com/2071-1050/12/14/5760/s1, Figure S1: Density functions for the satisfaction variable. Table S1: Relational coordination survey.

Author Contributions: Conceptualization and methodology, all authors. Formal analysis, software, data curation, data processing, Y.G.T., C.B. and J.L.M.-B.; statistical analysis, C.C. and J.L.M.-B.; validation and investigation, C.D.-P.-H. and A.G.; supervision, A.G., C.D.-P.-H. and C.C.; project administration, C.D.-P.-H. and A.G.; data acquisition, Y.G.T. and A.G. All authors have been involved in developing, writing, commenting, editing, and reviewing the manuscript. All authors have read and agreed to the published version of the manuscript.

Funding: This research received no external funding.

Acknowledgments: Thanks to Quevedo State Technical University for their collaboration in the collection of data and to OpenInnova High Performance Group at Rey Juan Carlos University and ECONGEST AGR267 Group at Córdoba University for the support to this research.

Conflicts of Interest: The authors declare no conflict of interest.

\section{References}

1. Ortega-Mohedano, J.; Rodríguez-Conde, M.J. Which is or should be the ideal level of participation of students of higher education in their own education? In Proceedings of the Sixth International Conference on Technological Ecosystems for Enhancing Multiculturality, Salamanca, Spain, 24-26 October 2018; pp. 190-198.

2. De-Pablos-Heredero, C.; Tigerstedt, C.; Checa, C.; García-Martínez, A. Application of relational coordination model in student's perception of quality. The case of ESPAM MFL University. In Proceedings of the 11th Annual International Conference of Education, Research and Innovation, Seville, Spain, 12-14 November 2018; pp. 5539-5545.

3. De-Pablos-Heredero, C.; Díaz-Ocampo, E.; Torres, Y.; Checa, C.; Barba, C.; García, A. Typology of relational coordination model in higher education: The case of Universidad Técnica Estatal de Quevedo, Ecuador. In Proceedings of the 11th International Conference on Education and New Learning Technologies, Palma, Spain, 1-3 July 2019; pp. 9616-9620.

4. Ijaz, A.; Irfan, S.M.; Shahbaz, S.; Awan, M.; Sabir, M. An empirical model of student satisfaction: Case of Pakistan public sector bussines school. J. Qual. Technol. Manag. 2011, 7, 91-114.

5. Dedeurwaerdere, T. Transdisciplinary sustainability science at higher education institutions: Science policy tools for incremental institutional change. Sustainability 2013, 5, 3783-3801. [CrossRef]

6. Kucharcikova, A.; Miciak, M.; Malichova, E.; Durisova, M.; Tokarcikova, E. The motivation of students at universities as a prerequisite of the education's sustainability within the business value generation context. Sustainability 2019, 11, 5577. [CrossRef]

7. Lee, M.; You, M. Psychological and behavioral responses in South Korea during the early stages of Coronavirus disease 2019 (COVID-19). Int. J. Environ. Res. Public Health 2020, 17, 2977. [CrossRef] [PubMed]

8. Aburto, N.; Pevzner, E.; Lopez-Ridaura, R.; Rojas, R.; Lopez-Gatell, H.; Lazcano, E.; Hernandez-Avila, M.; Harrington, T. Knowledge and adoption of community mitigation efforts in Mexico during the 2009 H1N1 pandemic. Am. J. Prev. Med. 2010, 39, 395-402. [CrossRef]

9. Orozco-Messana, J.; Martínez-Rubio, J.M.; Gonzálvez-Pons, A. Sustainable higher education development through technology enhanced learning. Sustainability 2020, 12, 3600. [CrossRef]

10. Gallego, M.C.; De-Pablos-Heredero, C.; Medina-Merodio, J.A. Relational coordination in online education. Interciencia 2015, 40, 869-874.

11. Margalina, V.M.; De-Pablos-Heredero, C.; Montes-Botella, J.L. Achieving quality in e-learning through relational coordination. Stud. High. Educ. 2017, 42, 1655-1670. [CrossRef]

12. Müller, U.; Lude, A.; Hancock, D.R. Leading schools towards sustainability. Fields of action and management strategies for principals. Sustainability 2020, 12, 3031. [CrossRef]

13. De-Pablos-Heredero, C.; Carreño, L.C.; Díaz-Ocampo, E.; Torres, Y.; Checa, C.; Barba, C.; García, A. Organizational quality level of two ecuadorian universities. University Tecnica Estatal de Quevedo vs Escuela Politécnica Superior Agropecuaria de Manabí, Ecuador. In Proceedings of the 14th International Technology, Education and Development Conference, Valencia, Spain, 2-4 March 2020; pp. 4933-4937.

14. De-Pablos-Heredero, C.; Díaz-Ocampo, E.; Torres, Y.; Checa, C.; Barba, C.; García, A. Organizational quality level of University Tecnica Estatal de Quevedo-Ecuador. In Proceedings of the 14th International Technology, Education and Development Conference, Valencia, Spain, 2-4 March 2020; pp. 4921-4925. 
15. Manuti, A.; Giancaspro, M.L. People make the difference: An explorative study on the relationship between organizational practices, employees' resources, and organizational behavior enhancing the psychology of sustainability and sustainable development. Sustainability 2019, 11, 1499. [CrossRef]

16. Santos, J.M.; Horta, H. The research agenda setting of higher education researchers. High. Educ. 2018, 76, 649-668. [CrossRef]

17. De-Esteban, D. Relational coordination in the entrepreneurial ecosystem. Esic Mark. Econ. Bus. J. 2020, 51, 159-181.

18. Gittell, J.H.; Seidner, R.; Wimbush, J. A relational model of how high-performance work systems work. Organ. Sci. 2010, 21, 490-506. [CrossRef]

19. Gittell, J.; Logan, C.; Cronenwett, J.; Foster, T.; Freeman, R.; Godfrey, M.; Vidal, D. Impact of relational coordination on staff and patient outcomes in outpatient surgical clinics. Health Care Manag. Rev. 2018, 44, 12-20. [CrossRef] [PubMed]

20. De-Pablos-Heredero, C.; Fernández-Renedo, C.; Medina-Merodio, A. Technical efficiency and organ transplant performance: A mixed-method approach. Int. J. Environ. Res. Public Health 2015, 12, 4869-4888. [CrossRef]

21. Luque-González, A.; Hernández-Zubizarreta, J.; De-Pablos-Heredero, C. Weaknesses within the processes of globalization in the textile sector and their relation to CSR through a DELPHI analysis: Ethical or aesthetic. Recer. Rev. Pensam. Anal. 2016, 19, 35-71.

22. De-Pablos-Heredero, C.; Carreño, A.L.; Checa, C.; Barba, C.; García, A. A tool to measure quality from sudent's perceived satisfaction. The cases of two universities: ARCADA UAS Finland and ESPAM MLF Ecuador. In Proceedings of the 13th International Technology, Education and Development Conference, Valencia, Spain, 11-13 March 2019; pp. 9960-9965.

23. De-Pablos-Heredero, C.; Díaz-Ocampo, E.; Torres, Y.; Checa, C.; Barba, C.; García, A. Student’s accumulated experience effect in the organizational model of the University Tecnica Estatal de Quevedo-Ecuador. In Proceedings of the 11th International Conference on Education and New Learning Technologies, Palma, Spain, 1-3 July 2019; pp. 9622-9626.

24. Teichler, U. Sistemas Comparados de Educación Superior en Europa. Marcos Conceptuales, Resultados Empíricos y Perspectiva de Futuro, 1st ed.; Octaedro-ICT; Institut de Ciències de l'Educació: Barcelona, Spain, 2010.

25. Zee, M.; Koomen, H.M. Teacher self-efficacy and its effects on classroom processes, student academic adjustment, and teacher well-being: A synthesis of 40 years of research. Rev. Educ. Res. 2016, 86, 981-1015. [CrossRef]

26. Salinas, A.M.J.; Morales, J.A.; Martínez, P. Satisfacción del estudiante y calidad universitaria: Un análisis explicativo en la unidad académica multidisciplinaria agronomía y ciencias de la Universidad Autónoma de Tamaulipas, México. Rev. Enseñanza Univ. 2008, 23, 39-55.

27. Jereb, E.; Jerebic, J.; Urh, M. Revising the importance of factors pertaining to student satisfaction in higher education. Organizacija 2018, 51, 271-285. [CrossRef]

28. Arambewela, R.; Hall, J. An empirical model of international student satisfaction. Asia Pac. J. Mark. Logist. 2009, 21, 555-569. [CrossRef]

29. Espinoza, O.; González, L.; McGinn, N.; Castillo, D.; Sandoval, L. Factors that affect post graduation satisfaction of Chilean university students. Stud. High. Educ. 2017, 44, 1023-1038. [CrossRef]

30. Palominos-Belmar, P.; Quezada-Llanca, L.; Osorio-Rubio, C.; Torres-Ortega, J.; Lippi-Valenzuela, L. Calidad de los servicios educativos según los estudiantes de una universidad pública en Chile. Rev. Iberoam. Educ. Super. 2016, 7, 130-142. [CrossRef]

31. Ortega-Mohedano, J. Calidad y Satisfacción de los Estudiantes Europeos de Educación Superior. Construcción de una Escala de Medida de la Calidad de Servicio Presencial y Electrónico. Ph.D. Thesis, University of Salamanca, Salamanca, Spain, November 2015.

32. Hanssen, T.E.S.; Solvoll, G. The importance of university facilities for student satisfaction at a Norwegian university. Facilities 2015, 33, 744-759. [CrossRef]

33. Petruzzellis, L.; D’Uggento, A.M.; Romanazzi, S. Student satisfaction and quality of service in Italian universities. Manag. Serv. Qual. 2006, 16, 349-364. [CrossRef]

34. Ja-Sawm, A.; Yan, Y. The relationship between the levels of students'satisfaction and their achievement at KANT KAW Education Center in Myanmar. Sch. Hum. Sci. 2016, 8, 38-52. 
35. Xuan-Lan, P.; Minh-Tien, P. The influence of education service quality level on student satisfaction -The research of the University of Law \& Economics HCMC Case. In Proceedings of the 9th International Days of Statistics and Economics, Prague, Czech Republic, 10-12 September 2015; pp. 1301-1315.

36. Sohail, M.S.; Shaikh, N.M. Quest for excellence in business education: A study of student impressions of service quality. Int. J. Educ. Manag. 2004, 18, 58-65. [CrossRef]

37. Cummings, P. Democracy and student discontent: Chilean student protest in the PostPinochet Era. J. Politics Lat. Am. 2015, 7, 49-84. [CrossRef]

38. Sánchez-Sánchez, M.D.; Montes-Botella, J.L. Dimensions of the Spanish cultural tourist: Definition of a behavior model. Esic Mark. Econ. Bus. J. 2019, 50, 313-339.

39. Schlesinger, W.; Cervera, A.; Pérez-Cabañero, C. Sticking with your university: The importance of satisfaction, trust, image, and shared values. Stud. High. Educ. 2016, 42, 2178-2194. [CrossRef]

40. Weng, S.S.; Liu, Y.; Yen-Ching Chuang, Y.C. Reform of Chinese universities in the context of sustainable development: Teacher evaluation and improvement based on hybrid multiple criteria decision-making model. Sustainability 2019, 11, 5471. [CrossRef]

41. Marqués-Sánchez, P.; García-Rodríguez, I.; Benítez-Andrades, J.A.; Portillo, M.C.; Pérez-Paniagua, J.; Reguera-García, M.M. A Cooperative interdisciplinary task intervention with undergraduate nursing and computer engineering students. Sustainability 2019, 11, 6325. [CrossRef]

42. Tsinidou, M.; Gerogiannis, G.; Fitsilis, P. Evaluation of the factors that determine quality. Qual. Assur. Educ. 2010, 18, 227-244. [CrossRef]

43. Mendez, D.; Macía, F. Análisis factorial confirmatorio de la escala de actitudes hacia la estadística. Cuad. Neuropsicol. 2007, 1, 174-371.

44. Reips, U.; Funke, F. Interval-level measurement with visual analogue scales in Internet-based research: VAS Generator. Behav. Res. Methods 2008, 40, 699-704. [CrossRef] [PubMed]

45. Garmendia, M.L. Análisis factorial: Una aplicación en el cuestionario de salud general de Goldberg, versión de 12 preguntas. Rev. Chil. Salud Pública 2007, 11, 57-65. [CrossRef]

46. Long, W.F. Dissonance detected by cluster analysis of responses to the approaches and study skills inventory for students. Stud. High. Educ. 2010, 28, 21-35. [CrossRef]

47. Hatch, D.; Bohlig, M. An empirical typology of the latent programmatic structure of community college student success programs. Res. High. Educ. 2016, 2016 57, 72-98. [CrossRef]

48. Özen, Y. The development of will perception scale and practice in a psycho-education program with its validity and reliability. Educ. Res. Rev. 2017, 9, 1125-1132. [CrossRef]

49. Rangel, J.; Perea, J.M.; De-Pablos-Heredero, C.; Espinosa-García, J.A.; Toro-Mujica, P.; Feijoo, M.; Barba, C.; García, A. Structural and technological characterization of tropical smallholder farms of dual-purpose cattle in Mexico. Animals 2020, 10, 86. [CrossRef]

50. Aldás, J.; Uriel, E. Análisis Multivariante Aplicado Con R, 2nd ed.; Ediciones Paraninfo: Madrid, Spain, 2017.

51. Gutiérrez-Cordero, M.; Segovia-Vargas, M.; Ramos-Escamilla, M. Análisis del riesgo de caída de cartera en seguros: Metodologías de "inteligencia artificial" vs "modelos lineales generalizados". Economía Informa 2017, 407, 56-86. [CrossRef]

52. Ainscough, L.; Stewart, E.; Colthorpe, K.; Zimbardi, K. Learning hindrances and self-regulated learning strategies reported by undergraduate students: Identifying characteristics of resilient students. Stud. High. Educ. 2017, 43, 2194-2209. [CrossRef]

53. Ballantine, J.; Guo, X.; Larres, P. Psychometric evaluation of the student authorship questionnaire: A confirmatory factor analysis approach. Stud. High. Educ. 2015, 40, 596-609. [CrossRef]

54. Lee, H.; Lee, J.; Makara, K.; Fishman, B.; Teasley, S. A cross-cultural comparison of college student' learning strategies for academic achievement between South Korea and the USA. Stud. High. Educ. 2015, 42, 169-183. [CrossRef]

55. Hanaysha, J.; Kumar, D.; Hilman, H. Service quality and rsatisfaction: Study on international students in universities of North Malaysia. Int. J. Manag. 2012, 2, 116-133.

56. Mayes, E. Student representation on school governance councils. In Technical Report for VicSRC Student Representation on School Governance Councils; VicSRC: Melbourne, Australia, 2016. 
57. Filho, W.L.; Pires-Eustachio, J.H.P.; Ferreira-Caldana, A.C.; Will, M.; Lange-Salvia, A.; Rampasso, I.S.; Anholon, R.; Platje, J.; Kovaleva, M. Sustainability leadership in higher education institutions: An overview of challenges. Sustainability 2020, 12, 3761. [CrossRef]

58. Lee, Y.H.; Kim, K.S.; Lee, K.H. The effect of tuition fee constraints on financial management: Evidence from Korean private universities. Sustainability 2020, 12, 5066. [CrossRef]

(C) 2020 by the authors. Licensee MDPI, Basel, Switzerland. This article is an open access article distributed under the terms and conditions of the Creative Commons Attribution (CC BY) license (http://creativecommons.org/licenses/by/4.0/). 